\title{
Massive pulmonary haemorrhage in the newborn
}

\section{A changing pattern ${ }^{\star}$}

\author{
C. B. BOOTHBY† and D. J. DESA \\ From the Departments of Paediatrics and Pathology, Radcliffe Infirmary, Oxford
}

\begin{abstract}
Boothby, C. B., and deSa, D. J. (1973). Archives of Disease in Childhood, 48, 21. Massive pulmonary haemorrhage in the newborn: a changing pattern. During the years 1969-71 an increased incidence of massive pulmonary haemorrhage among early neonatal deaths in the United Oxford Hospitals was noticed. When compared to an earlier survey in the same hospitals no change in the distribution by birthweight score of the affected infants was seen. The increased incidence of the syndrome coincided with a fall in the perinatal mortality rate. An analysis of the clinical features and pathological findings in the affected infants showed that certain known causes of the syndrome, like antepartum haemorrhage and hypothermia, were still present. In 7 of the 11 cases, however, there was histological evidence of oxygen toxicity. It is suggested that the use of high concentrations of oxygen contributed to the increased incidence of the syndrome.
\end{abstract}

An analysis of cases of massive pulmonary haemorrhage (MPH) occurring in newborn infants in the United Oxford Hospitals between the years 1948-61 showed that there was no single aetiological factor and that, to a very great extent, the syndrome was preventable (deSa and MacLean, 1970). A falling incidence of the syndrome that parallelled the decline in the stillbirth and neonatal mortality rate was shown. In the past three years (1969-71), however, MPH appeared to be seen more frequently in the same population. This report presents a study of the cases with MPH during the years 1969-71 in the United Oxford Hospitals.

\section{Material and methods}

The necropsy records of the neonatal deaths are filed in the Department of Pathology of the Radcliffe Infirmary, Oxford, and these records were available for analysis. A histological definition of MPH was necessary and the one used was identical to that used in the earlier survey (deSa and MacLean, 1970). MPH was considered to be present if there was confluent haemorrhage, either alveolar or interstitial in type, involving two or more lobes of the lung in the absence of infection.

Thirteen early neonatal deaths with lung histology that conformed to this definition were traced. For the

\footnotetext{
Received 19 May 1972.

*Based on a paper presented to the Neonatal Society, London, 3 February 1972.

tPresent address: West Suffolk General Hospital, Bury St. Edmund's.
}

purposes of this study the definition of early neonatal death was the one currently in use in this country, i.e. a death occurring in the first 7 days of life. The clinical notes of these cases were traced and details of gestation, birthweight, mode of delivery, complications of pregnancy, delivery, and postnatal life, therapy, and feeding extracted.

During this period there were 13,935 births and of these 13,781 were livebirths.

\section{Results}

Two of the infants with MPH had severe congenital malformations (Table I) and as in the earlier survey (deSa and MacLean, 1970) are not considered further.

TABLE I

Congenital malformations and $M P H$

\begin{tabular}{c|c}
\hline Case no. & \multicolumn{1}{|c}{ Malformation } \\
\hline 1 & $\begin{array}{c}\text { Anomalous pulmonary venous drainage, common } \\
\text { ventricle, aortic hypoplasia } \\
\text { Preductal coarctation, ventricular septal defect, renal } \\
\text { dysplasia, single umbilical artery }\end{array}$ \\
\hline
\end{tabular}

The 11 remaining cases with $\mathrm{MPH}$ represented an incidence of 0.8 per 1000 livebirths. As shown in Fig. 1, this represented an increase when compared to the average incidence of the syndrome in the same population over the preceding 7 years $\left(\chi^{2}=18 \cdot 8 ; P<0.001\right)$. The rise was even more 


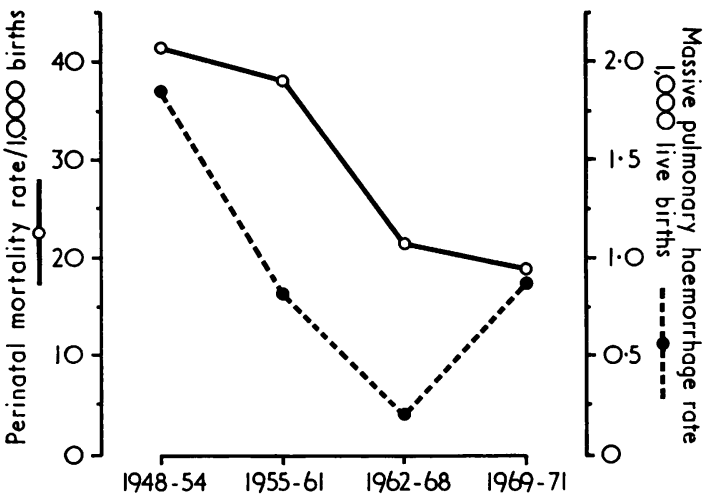

FIG. 1.-Comparison of the perinatal mortality rate with the MPH rate in the United Oxford Hospitals between 1948 and 1971, both years inclusive.

remarkable since it coincided with a slight drop in perinatal mortality. The apparent reversal of the trend noted in the earlier survey prompted a closer examination.

Birthweight score and MPH. The cases of MPH in the national series of the 1958 Perinatal Mortality Survey (Gruenwald, 1969b) were analysed and presented according to the birthweight score $\frac{D}{\omega}$. of the infected infants. The cases of the earlier $\bigcirc$ Oxford series (deSa and MacLean, 1970) were $\overline{\bar{Q}}$. analysed in the same way, and it was shown then that the Oxford series contained far fewer infants of low birthweight score (' -1 ' and ' -2 ') than were anticipated from the national figures of Gruenwald, $(1969 a, b)$. The cases of MPH in the series of Gruenwald (1969b), the earlier series (deSa and MacLean, 1970), and the present series were separated into their respective birthweight score groups and the numbers in each group were represented as a percentage of the total in the group. As seen in Fig. 2 there was no significant difference in the distribution of the cases in respect of their birthweight score between the earlier series and the current one. In both Oxford series there were relatively few infants of low birthweight score when compared to the national figures.

Factors associated with MPH. Several aetiological factors were apparent on reading the clinical notes (Table II).

Antepartum haemorrhage. There were 3 infants whose mothers had had severe antepartum haemorrhages. In one infant (Case 3 ) much of the ante- $\overrightarrow{0}$

TABLE II

Clinical features in 11 cases of MPH

\begin{tabular}{|c|c|c|c|c|c|c|c|c|}
\hline $\begin{array}{l}\text { Case } \\
\text { no. }\end{array}$ & $\begin{array}{l}\text { Gestation } \\
\text { (wk) }\end{array}$ & $\begin{array}{l}\text { Birth- } \\
\text { weight } \\
\text { (g) }\end{array}$ & $\begin{array}{l}\text { Birth- } \\
\text { weight } \\
\text { score* }\end{array}$ & $\begin{array}{c}\text { Complications } \\
\text { of } \\
\text { pregnancy }\end{array}$ & $\begin{array}{l}\text { Complications } \\
\text { of postnatal } \\
\text { life }\end{array}$ & $\begin{array}{l}\text { Age } \\
(\mathbf{h r})\end{array}$ & $\begin{array}{l}\text { Associated findings } \\
\text { at necropsy other } \\
\text { than MPH }\end{array}$ & $\begin{array}{l}\text { Atypical } \\
\text { histology } \\
\text { in lungs }\end{array}$ \\
\hline 1 & 26 & 820 & 0 & Premature labour & $\begin{array}{l}\text { Apnoeic attacks from } \\
\text { birth hypothermia }\end{array}$ & 62 & & Present \\
\hline 2 & 27 & 890 & 0 & Premature labour & Apnoeic attacks & 8 & & Present \\
\hline 3 & 28 & 1360 & 0 & $\begin{array}{l}\text { Antepartum } \\
\text { haemorrhage }\end{array}$ & $\begin{array}{l}\text { Apnoeic, requiring } \\
\text { increasing oxygen } \\
\text { concentration }\end{array}$ & 109 & $\begin{array}{l}\text { Bilateral segmental } \\
\text { adrenal necrosis }\end{array}$ & Present \\
\hline 4 & 30 & 1985 & +1 & $\begin{array}{l}\text { Antepartum } \\
\text { haemorrhage }\end{array}$ & $\begin{array}{l}\text { Cyanosed at birth; } \\
\text { unable to maintain } \\
\text { respiration }\end{array}$ & 4 & $\begin{array}{l}\text { Subdural } \\
\text { haematoma and } \\
\text { tentorial tear }\end{array}$ & \\
\hline 5 & 32 & 1080 & -1 & $\begin{array}{l}\text { Second of undiag- } \\
\text { nosed twins }\end{array}$ & $\begin{array}{l}\text { Apnoea followed by } \\
\text { respiratory distress; } \\
\text { hypothermia }\end{array}$ & 69 & $\begin{array}{l}\text { Intraventricular } \\
\text { haemorrhage; } \\
\text { capillary thrombi }\end{array}$ & Present \\
\hline 6 & 32 & 1588 & 0 & $\begin{array}{l}\text { Antepartum } \\
\text { haemorrhage }\end{array}$ & Respiratory distress & 23 & & \\
\hline 7 & 33 & 1150 & -1 & $\begin{array}{l}\text { Fetal distress, } \\
\text { caesarean section }\end{array}$ & Hypothermia & 94 & & \\
\hline 8 & 34 & 2000 & 0 & $\begin{array}{l}\text { Maternal drug } \\
\text { addiction }\end{array}$ & $\begin{array}{l}\text { Respiratory distress; } \\
\text { hypocalcaemia; } \\
\text { hypothermia }\end{array}$ & 114 & $\begin{array}{l}\text { Intraventricular } \\
\text { haemorrhage }\end{array}$ & Present \\
\hline 9 & 36 & 1360 & -2 & $\begin{array}{l}\text { No antenatal } \\
\text { details known }\end{array}$ & $\begin{array}{l}\text { Hypothermia; apnoeic } \\
\text { attacks }\end{array}$ & 46 & & \\
\hline 10 & 39 & 1810 & -2 & $\begin{array}{l}\text { Fetal distress, } \\
\text { caesarean section }\end{array}$ & $\begin{array}{l}\text { Respiratory distress; } \\
\text { hypothermia; } \\
\text { hypoglycaemia }\end{array}$ & 112 & $\begin{array}{l}\text { Primary meningeal } \\
\text { haemorrhage; } \\
\text { capillary thrombi }\end{array}$ & Present \\
\hline 11 & 40 & 3216 & 0 & $\begin{array}{l}\text { No known } \\
\text { complications }\end{array}$ & $\begin{array}{l}\text { Apnoeic attacks from } \\
36 \mathrm{hr} \text { requiring } \\
\text { resuscitation and } \\
\text { constant ventila- } \\
\text { tion; hypothermia }\end{array}$ & 96 & $\begin{array}{l}\text { Subdural } \\
\text { haematoma and } \\
\text { tentorial tear }\end{array}$ & Present \\
\hline
\end{tabular}

$\star 0$, birthweight within 1 SD of the mean for that gestation; +1 or -1 , birthweight between 1 and 2 SDs above or below mean, respectively; +2 or -2 , birthweight varying by more than 2 SDs above or below mean. 


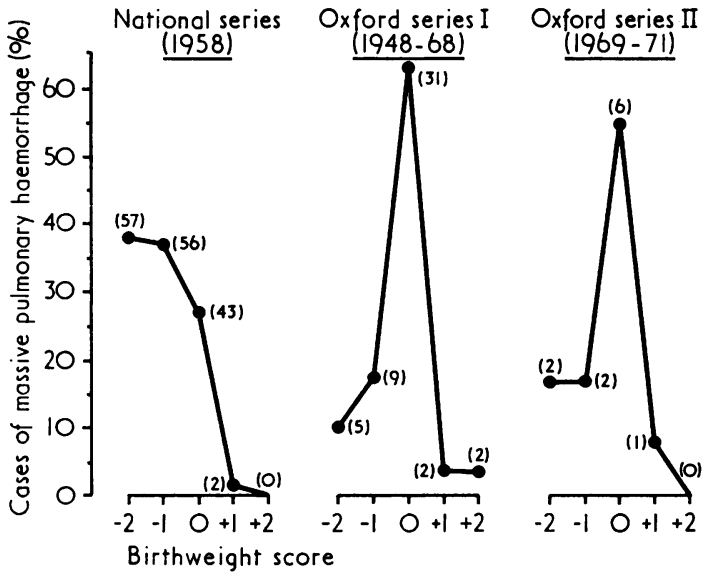

FIG. 2.-Distribution of infants with $M P H$ by birthweight score. 'National Series' refers to the findings of the 1958 Perinatal Mortality Survey (Gruenwald, 1969b), and 'Oxford Series I' refers to the findings of deSa and MacLean (1970). Figures in parentheses refer to the actual numbers of cases in each category.

partum bleeding had been retroplacental, and on examining the placenta $130 \mathrm{~g}$ retroplacental clot covering most of the maternal surface was found.

Other complications of pregnancy. 2 infants (Cases 1 and 2) were delivered at an extremely immature gestation. There were 2 infants where fetal distress during labour led to their delivery by caesarean section. One infant (Case 5) was the second twin in an undiagnosed multiple preg- nancy who was delivered precipitately at home. No details of the antenatal period were known of in Case 9 and there were no known complications of pregnancy in Case 11.

Postnatal complications. As is evident from Table II there were severe problems in the initiation and maintenance of respiration in Cases 1 to 10 . The most mature infant (Case 11) appeared to be progressing normally after birth until at about $\mathbf{3 0}$ hours it was noticed to have a high-pitched cry and began to have apnoeic attacks that required constant ventilation until its death.

Hypothermia. This was defined as a body temperature of $34.4{ }^{\circ} \mathrm{C}$ or less, and 7 of the infants were classed as being hypothermic.

Other features. One infant (Case 8 ) had a serum calcium of $2.6 \mathrm{mEq} / 1$., and another (Case 10) had a blood sugar level of less than $14 \mathrm{mg} / 100 \mathrm{ml}$ in the first hour of life.

Feeding. 3 infants were fed with milk during the first 12 hours of life in amounts comparable to those recommended by Smallpeice and Davies (1964). 7 infants were treated with intravenous infusions of laevulose and/or glucose; subsequently 2 of these infants were fed with milk at the age of 24 and 72 hours. The former infant is of interest in that it had evidence of hypocalcaemia. In one infant no information regarding feeding was available.

No details regarding the levels of coagulation factors were available in any of the cases.

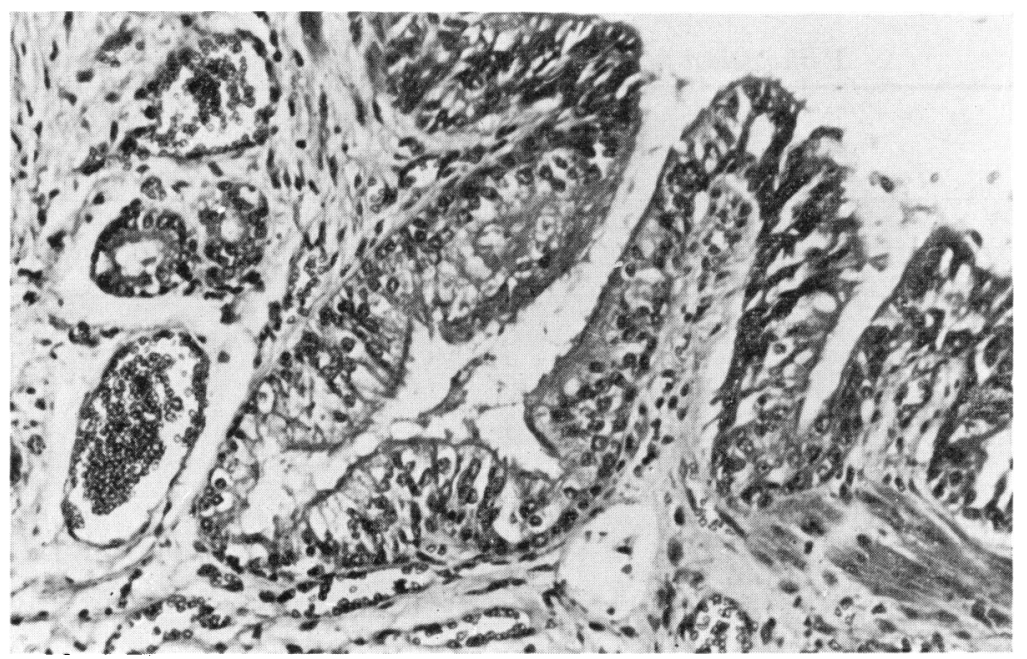

FIG. 3.-Major bronchus showing focal epithelial necrosis characterized by ballooning and distension of the cytoplasm

(Case 2). There is a variable degree of nuclear pyknosis or swelling as well. $(H$. and E. $\times 160$.) 
Pathological findings. Table II lists the main pathological findings apart from $\mathrm{MPH}$ found at necropsy. Bilateral segmental necrosis of the adrenal gland represents the commonest form of haemorrhagic necrosis in the perinatal period and is of ischaemic origin (deSa and Nicholls, 1972), while the entity referred to as primary meningeal haemorrhage is the lesion that has been associated by Chessells and Wigglesworth (1970) with disseminated intravascular coagulation. It can be seen that disseminated capillary thrombi were found in Cases 5 and 10 and in both cases these were seen most readily in the sinusoids of subcapsular hepatic lobules and in the capillary channels of the provisional (fetal) adrenal cortex. The remaining associated pathological findings do not require any further comment.

Histological findings. In 4 cases histological examination of the lungs showed extensive bland zones of interstitial and alveolar haemorrhage as might be expected from the definition used to ascertain our cases.

In the 7 remaining cases, there were, in addition, certain unusual histological findings that warranted their being separated into a homogeneous subgroup of their own. The changes that are to be described were found to a varying extent in all the 7 infants and are summarized in Table III. The epithelium of main and lobar bronchi showed patchy areas of coagulative necrosis characterized by a loss of cilia, a blurring of cell margins, vacuolation of both cytoplasm and nucleus, and considerable variability of nuclear size (Fig. 3). In the older infants

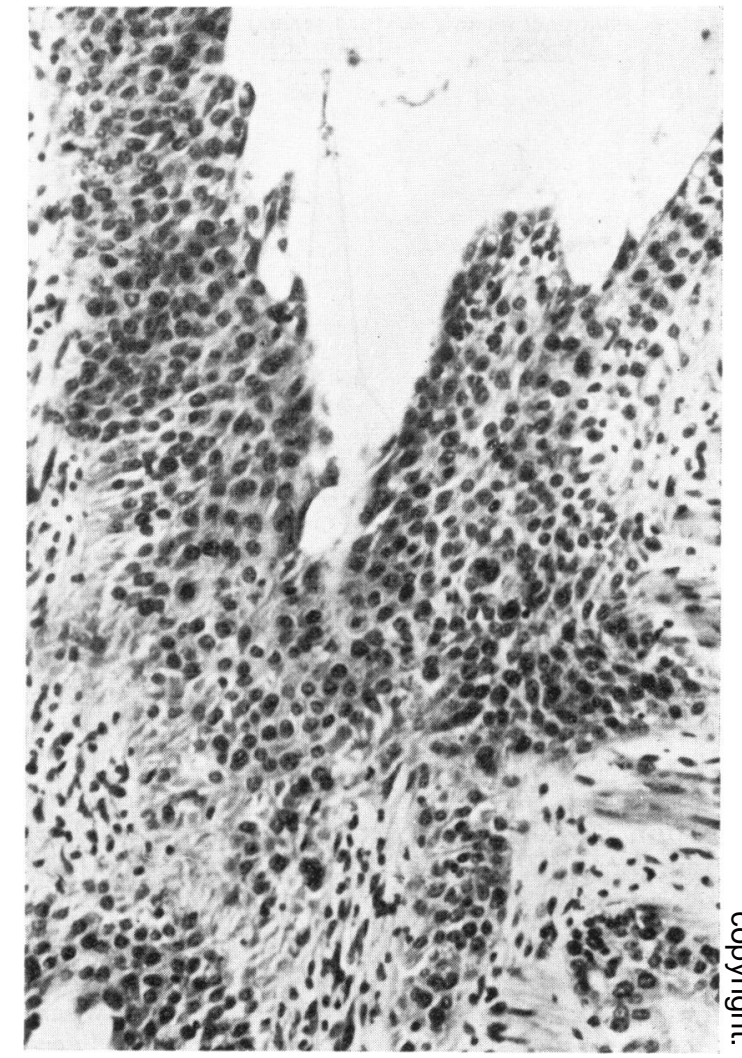

FIG. 4.-Bizarre epithelial regeneration in a lobar bronchus producing a squamous epithelium (Case 8). Note the very high mitotic rate. $(H$. and $E . \times 176$.)

TABLE III

Pathological findings ('oxygen toxicity') in 7 cases

\begin{tabular}{|c|c|c|c|c|c|c|c|}
\hline & & & & Case No. & & & \\
\hline & 1 & 2 & 3 & 5 & 8 & 10 & 11 \\
\hline Gestation (wk) & 26 & 27 & 28 & 32 & 34 & 39 & 40 \\
\hline Age (hr) & 62 & 8 & 109 & 69 & 114 & 112 & 96 \\
\hline $\begin{array}{l}\text { Bronchial epithelium } \\
\text { (a) necrosis } \\
\text { (b) regeneration }\end{array}$ & $\begin{array}{c}++ \\
+++\end{array}$ & $\begin{array}{c}++ \\
\text { Absent }\end{array}$ & $\stackrel{+}{+}+$ & $\begin{array}{c}+ \\
++\end{array}$ & $\begin{array}{c}+ \\
++\end{array}$ & $\stackrel{+}{+}$ & + \\
\hline $\begin{array}{l}\text { Bronchiolar epithelium } \\
\text { (a) necrosis } \\
\text { (b) regeneration }\end{array}$ & $\begin{array}{c}++ \\
+++\end{array}$ & $\begin{array}{c}++ \\
+++\end{array}$ & $\begin{array}{l}++ \\
++\end{array}$ & $\begin{array}{l}++ \\
++\end{array}$ & $\begin{array}{c}++ \\
+++\end{array}$ & $\begin{array}{c}++ \\
+++\end{array}$ & $\begin{array}{l}++ \\
++\end{array}$ \\
\hline $\begin{array}{l}\text { Alveolar septum } \\
\text { (a) epithelial necrosis } \\
\text { (b) regeneration } \\
\text { (c) oedema } \\
\text { (d) fibrosis } \\
\text { (e) organization of exudate } \\
\text { (f) new vessel formation }\end{array}$ & $\begin{array}{c}++ \\
+ \\
++ \\
\text { Possible } \\
+ \\
\text { Absent }\end{array}$ & $\begin{array}{c}++ \\
+ \\
+ \\
\text { Absent } \\
\text { Absent } \\
\text { Absent }\end{array}$ & $\begin{array}{l}+ \\
++ \\
++ \\
\text { Possible } \\
+ \\
+\end{array}$ & $\begin{array}{c}+ \\
++ \\
+ \\
\text { Absent } \\
+ \\
\text { Absent }\end{array}$ & $\begin{array}{c}+++ \\
++ \\
++ \\
\text { Probable } \\
+ \\
++\end{array}$ & $\begin{array}{l}++ \\
+++ \\
+++ \\
\text { Probable } \\
++ \\
++++\end{array}$ & $\begin{array}{c}+ \\
++ \\
+ \\
\text { Possible } \\
+ \\
+\end{array}$ \\
\hline
\end{tabular}

Note: + to ++++ , grades of severity. 


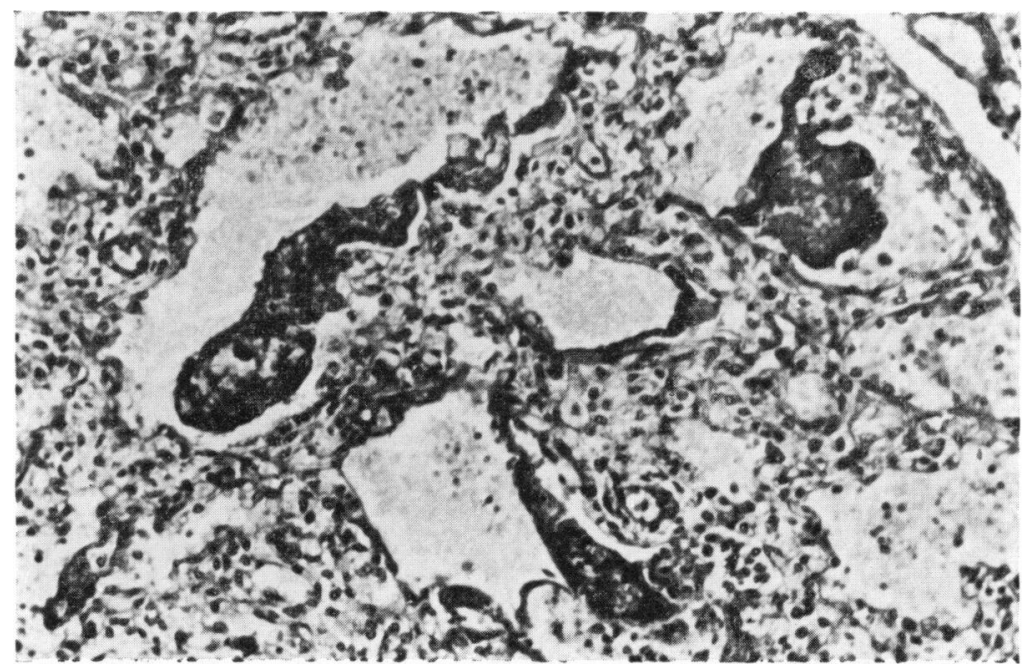

FIG. 5.-Bronchiolar epithelial necrosis producing a membranous exudate (Case 2). There is moderate dilatation of the lumen of the affected bronchioles. (Picro-Mallory. $\times 83$.)

areas of regeneration of the bronchial epithelium occurring simultaneously with scattered areas of focal necrosis were seen, and occasionally a bizarre metaplastic epithelium with a pronounced resemblance to squamous epithelium was seen (Fig. 4). The bronchioles were not spared and conspicuous dilatation of the terminal bronchioles with the production of a membranous exudate due to the associated necrosis of the bronchiolar epithelium was present in every case (Fig. 5). In other bronchioles there were areas of bizarre regeneration (Fig. 6) producing considerable distortion of the bronchiolar architecture.

Since the bronchiolar changes were present in every single case, including Case 2 (aet. 8 hours) from whose lungs the field for Fig. 6 was selected, we believe that they represent one of the earliest of the changes seen.

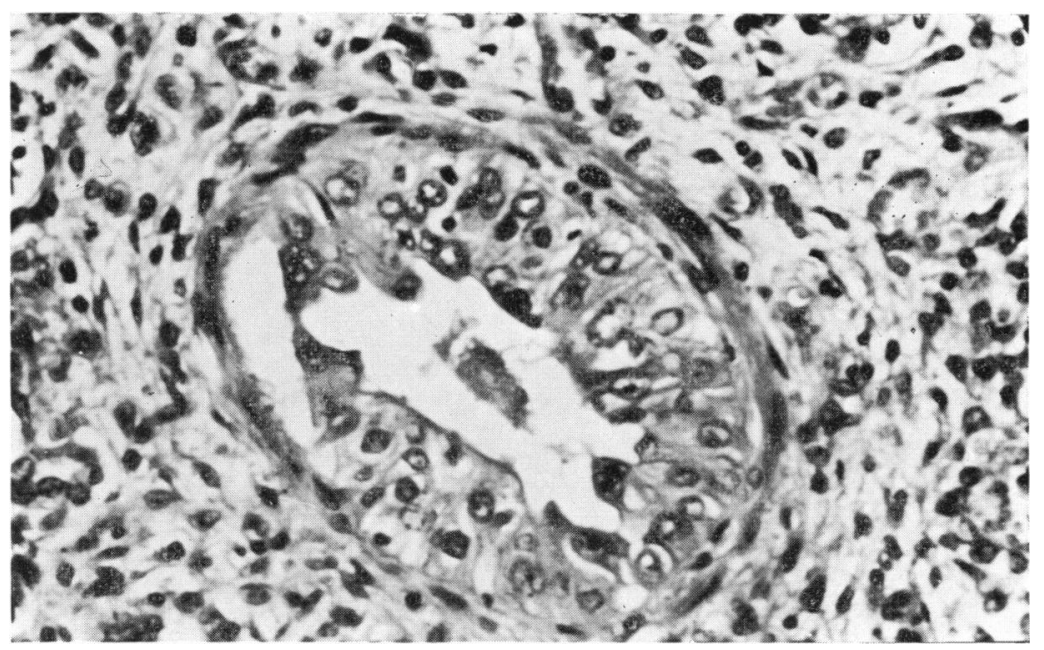

FIG. 6.-Bizarre regeneration of bronchiolar epithelium with pseudostratification and nuclear variability (Case 2). (H. and E. $\times 256$.) 


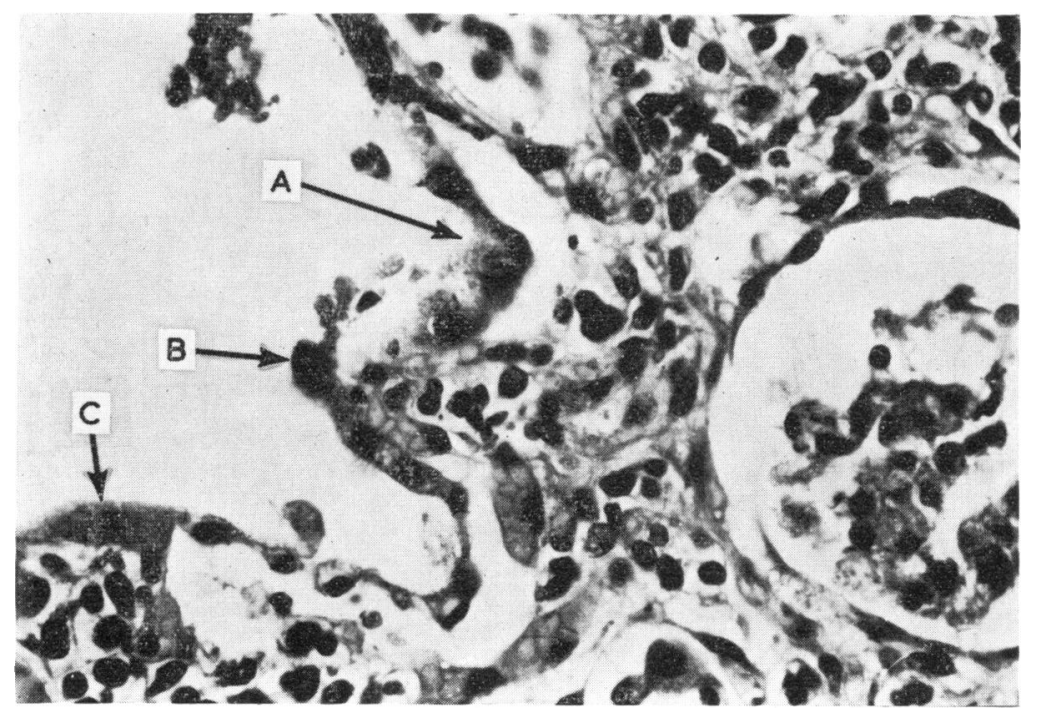

FIG. 7.-Various patterns of alveolar epithelial necrosis are shown with karyolysis $(A)$, karyorrhexis $(B)$, and pyknosis $(C) . \quad(H$. and $E . \times 262$.)

The alveolar septal epithelium was grossly abnormal with extensive areas of necrosis (Fig. 7), and this was associated in the older infants with evidence of regeneration of the epithelium (Fig. 8). In the 6 older infants there was good evidence of organization of haemorrhagic and necrotic exudate by macrophages and capillary ingrowth (Fig. 9). The septum itself often showed conspicuous widening while near the central zone of the lung lobule there was more obvious widening due to a combination of both interstitial oedema and possible fibrous thickening (Fig. 10). The most $\vec{\theta}$ surprising feature in the 6 older infants was th 8 presence of newly formed capillary channe developing in and spreading out from the centrati areas of the lobule (Fig. 11). Capillary dilatation was particularly prominent and in some cases areas of capillary rupture could be observed (Fig. 12).

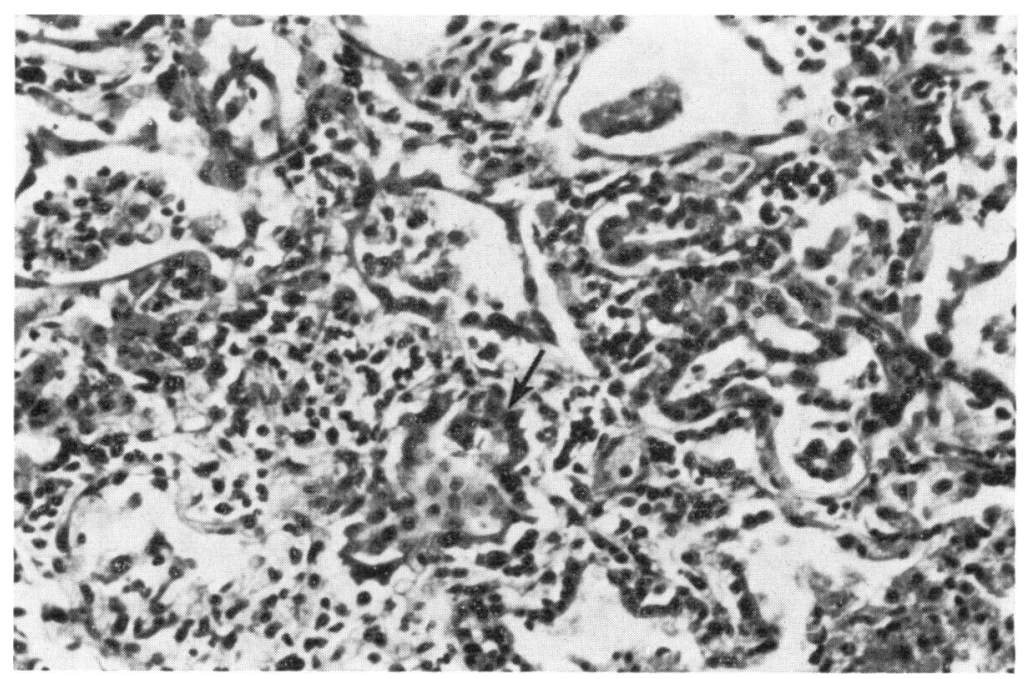

FIG. 8.- $A$ focal zone of alveolar epithelial regeneration and consequent epithelialization (Case 3 ). In one airspace the $\stackrel{\mathscr{N}}{+}$ lumen is occupied by a clump of regenerated cells (arrow). H. and E. $\times 174$.) 


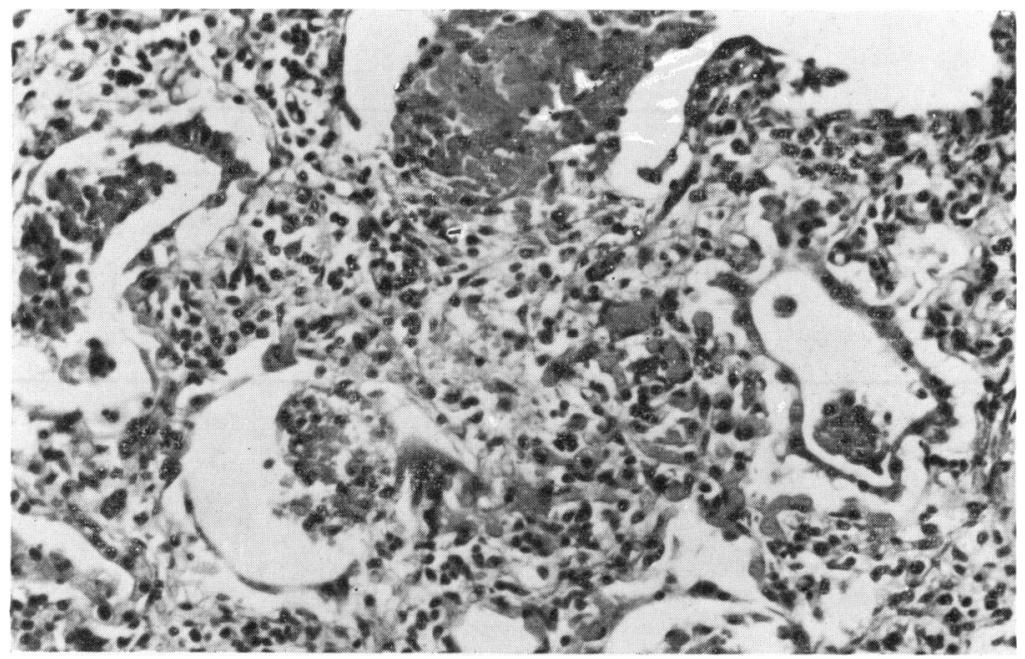

FIG. 9.-Early organization of haemorrhagic and necrotic exudate in airspace (Case 8). Note the development of new capillary channels and the adjacent alveolar epithelialization. (H. and $E$. $\times 160$.

These necrotic changes irregularly associated with concomitant areas of bizarre epithelial regeneration, fibroplasia, and vasoformative changes are similar to the changes described both in expermental animals and human newborn infants exposed to high partial pressures of oxygen (Northway, Rosan, and Porter, 1967; Northway et al., 1969).

Oxygen therapy and MPH. The details of oxygen therapy received by the infants in our series are shown in Table IV. It can be seen that in the 7 infants with histological changes of oxygen toxicity there was good evidence that high concentrations of ambient oxygen were used in 5 cases. The infants who appeared to be most at risk were those who received high concentrations of oxygen ( $>80 \%$ ) for a period greater than 24 hours. Only 4 of our cases with oxygen toxicity had been ventilated.

It was apparent that in nearly all of the cases receiving added oxygen there was reason to suspect the

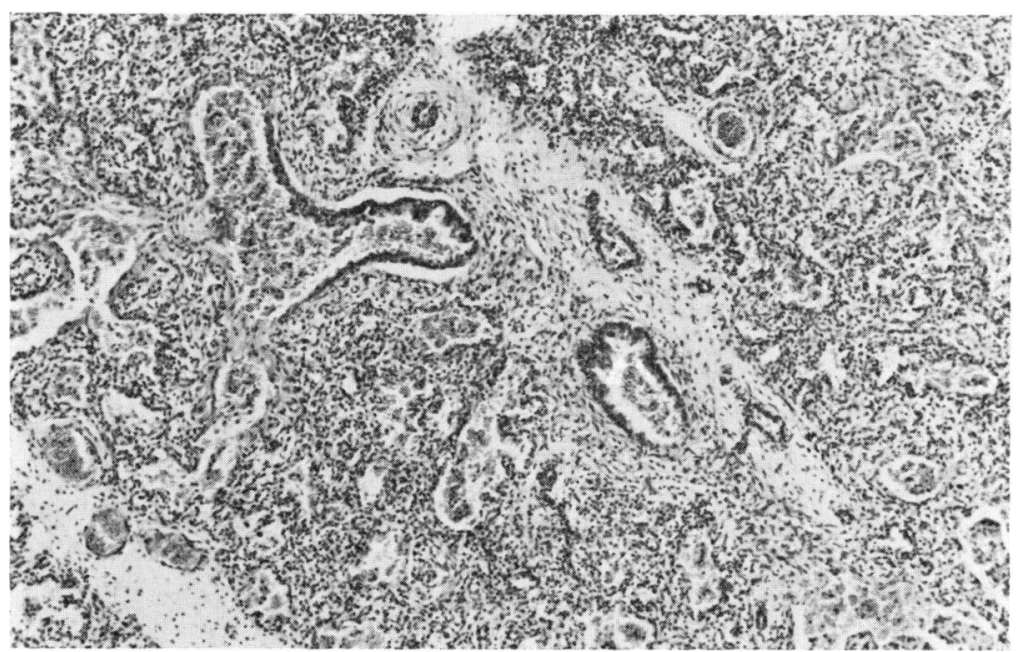

FIG. 10.-Oedema and fibrosis of the alveolar septum can be seen, the latter change being most marked towards the central zone of the lobule (Case 1). (H. and E. $\times 56$.) 


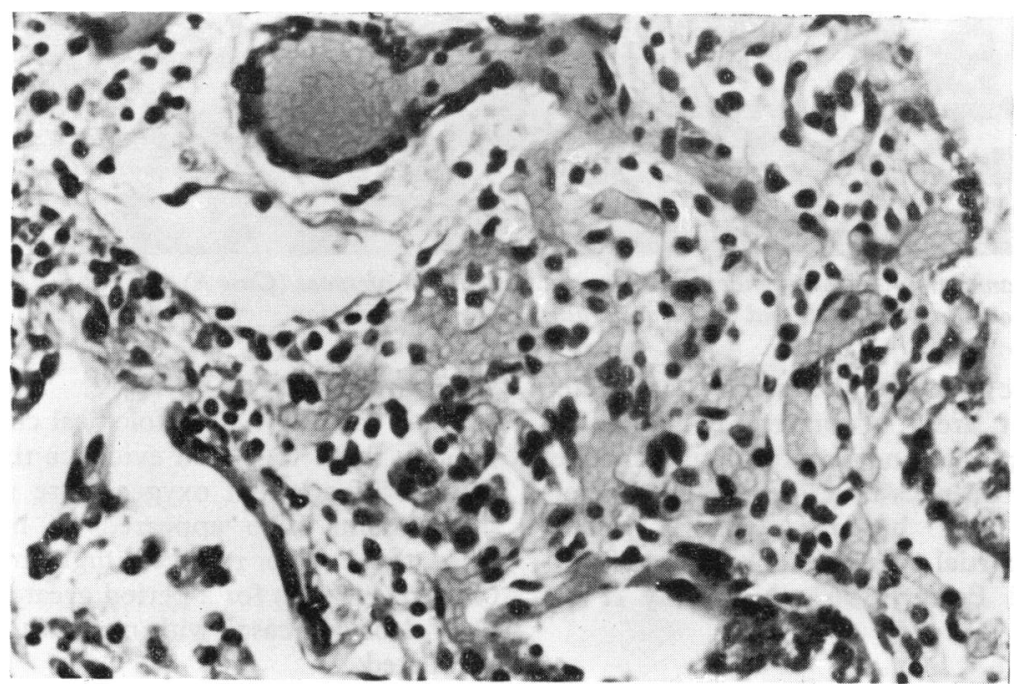

Fig. 11.-A coil of newly formed vessels can be seen near the central zone of a lobule (Case 8). (H. and E. $\times 262$.

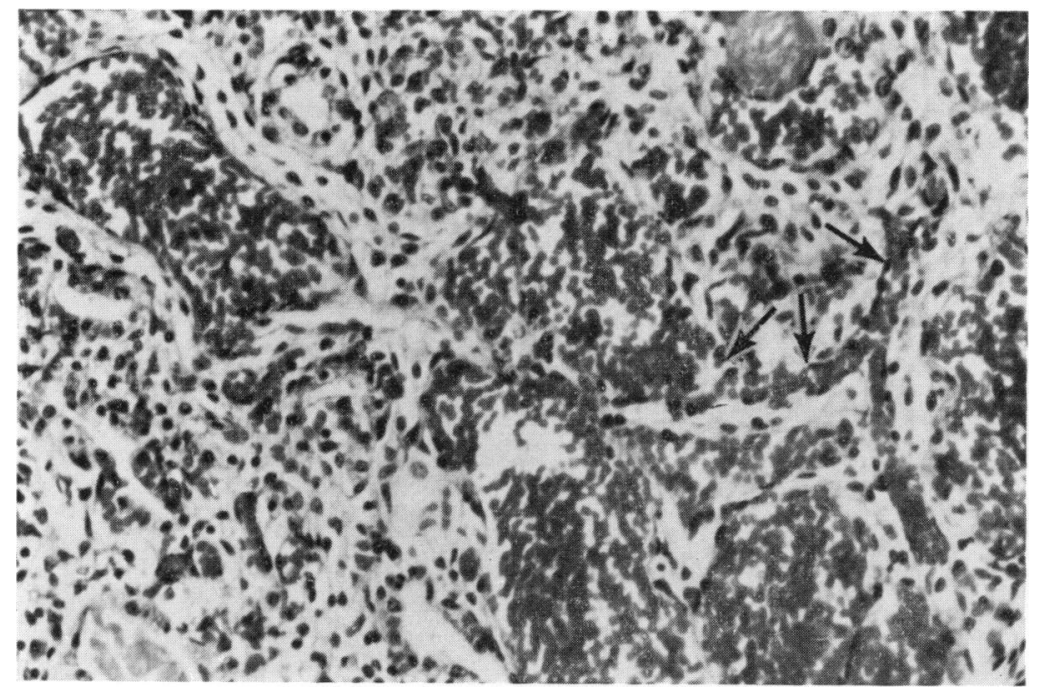

FIG. 12.-The section shows a dilated capillary channel leading up to a point of rupture into an air space (arrows) (Case 11). (H. and E. $\times 175$.) 


\begin{tabular}{|c|c|c|c|c|c|}
\hline 6 & 7 & 8 & 9 & 10 & 11 \\
\hline $\begin{array}{c}\text { Birth } \\
\text { c. } 100 \% \\
23 \mathrm{hr} \\
\text { Respiratory distress }\end{array}$ & $\begin{array}{l}\text { No therapy } \\
\text { No therapy } \\
\text { No therapy } \\
\text { No therapy }\end{array}$ & $\begin{array}{c}\text { Birth } \\
100 \% \\
114 \mathrm{hr} \\
\text { Respiratory distress }\end{array}$ & $\begin{array}{c}\text { Birth } \\
40 \% \\
46 \mathrm{hr} \\
\text { Apnoeic attacks }\end{array}$ & $\begin{array}{c}\text { Birth } \\
80 \% \\
112 \mathrm{hr} \\
\text { Respiratory distress }\end{array}$ & $\begin{array}{c}36 \mathrm{hr} \\
100 \% \\
60 \mathrm{hr} \\
\text { Apnoeic attacks }\end{array}$ \\
\hline $\begin{array}{l}\text { Yes } \\
\text { No }\end{array}$ & $\begin{array}{l}\text { No therapy } \\
\text { No therapy }\end{array}$ & $\begin{array}{l}\text { Yes } \\
\text { Yes }\end{array}$ & $\begin{array}{l}\text { No } \\
\text { No }\end{array}$ & $\begin{array}{l}\text { No } \\
\text { Yes }\end{array}$ & $\begin{array}{l}\text { Yes } \\
\text { Yes }\end{array}$ \\
\hline
\end{tabular}

presence of at least one underlying cause of lung damage, as shown by a comparison of Tables II and IV. It was difficult to explain why Case 6 did not develop changes of oxygen toxicity, since a high concentration of ambient oxygen was received with ventilation. It will be noticed that Case 9, ventilated for 46 hours with only $40 \%$ oxygen, did not develop changes of oxygen toxicity. The total exposure of Case 4 was probably too short to allow any changes to develop and Case 7 received no added oxygen.

\section{Discussion}

The obvious rise in the incidence of $\mathrm{MPH}$ in the years 1969-71 cannot be attributed to any general rise in the perinatal mortality rate, nor can it be attributed to any significant change in distribution of affected infants. It is obvious that some other explanation for our results must be sought.

We believe that the histological changes illustrated are those of oxygen toxicity and 'bronchopulmonary dysplasia' with superadded massive pulmonary haemorrhage, since they are identical in all essential features to those described by Northway et al. (1967) in newborn infants exposed to high concentrations of oxygen and mechanical ventilation. The findings in our infants are surprising in one respect in that they suggest that toxic changes may occasionally be seen after a relatively short period of exposure, and the bronchiolar changes depicted in Fig. 6 offer a striking example. It is interesting, on rereading the paper of Northway et al. (1967), to note that they found that, 'In the individual patient, several pathologic states of the lesions characteristically exist at the same time, and the radiologic and pathologic stages overlap slightly'. Their 'idealized' staging, is, therefore, difficult to evaluate since none of our infants lived as long as theirs. The histological changes in the young adult rats of body weight 90 to $100 \mathrm{~g}$ used by Harrison, Rosan, and Sloane (1970), and newborn guinea-pigs (Northway et al., 1969), offer better comparisons, and again the authors emphasize that all the histological stages overlap. The first and second cases of Rowland and Newman (1969) show a similar degree of rapidity of change to ours.

We recognize that our records lack sufficient detail to delineate clearly the limits of safety of oxygen therapy. However, in our small series ventilation per se was not an essential component as far as the development of oxygen toxicity was concerned. This finding is supported by experimental evidence, reviewed by Avery (1970), that the dysplastic changes are likely to be due to the use of high concentrations of oxygen over long periods of time.

There is a considerable similarity in the changes of oxygen toxicity in 7 of the infants in our series and those described in retrolental fibroplasia. It is tempting to assume that the process in the lung as in the eye is one of vasoconstriction (Patz, 1965). In view of the likelihood of underlying lung damage and pulmonary hypoperfusion (Chu et al., 1965) in our infants before any oxygen therapy, additional vasoconstriction could conceivably produce very deleterious results. This might explain why the histological changes in infants appear to be exaggerated in their intensity and rapidity.

Unfortunately, the vascular changes in the lungs of newborn infants exposed to high concentrations of oxygen are not always described in detail in the literature (see Northway et al., 1967; Hawker, Reynolds, and Taghizadeh, 1967; Rowland and Newman, 1969). This is disappointing in view of the suggested association of therapeutic oxygen and pulmonary haemorrhage (Shanklin and Wolfson, 1967), and the fact that high concentrations of oxygen can damage capillary endothelium (Kistler, Caldwell, and Weibel, 1967). Vascular damage is implicit in any haemorrhagic phenomenon, and it would not be surprising, therefore, if the use of high concentrations of oxygen operated as an exacerbating factor in 7 of our cases. If such an interpretation is correct, then it would seem likely 
that the recent increase in the incidence if $\mathrm{MPH}$ that we have experienced may be attributed, in part at least, to the use of high concentrations of oxygen.

We are grateful to Dr. A. H. T. Robb-Smith, Director of Pathology, for permission to study the necropsy records; to Drs. H. Ellis and B. D. Bower for agreeing to let us study the clinical notes of their patients, and to Dr. A. Barr for guidance with the statistical analysis. Dr. T. M. Parry and Mr. D. Luckett prepared the photomicrographs.

\section{REFERENCES}

Avery, M. E. (1970). What is bronchopulmonary dysplasia? Human Pathology, 1, 321.

Chessells, J. M., and Wigglesworth, J. S. (1970). Secondary haemorrhagic disease of the newborn. Archives of Disease in Childhood, 45, 539.

Chu, J., Clements, J. A., Cotton, E., Klaus, M. H., Sweet, A. Y., Thomas, M. A., and Tooley, W. H. (1965). The pulmonary hypoperfusion syndrome. Pediatrics, 35, 733.

deSa, D. J., and MacLean, B. S. (1970). An analysis of massive pulmonary haemorrhage in the newborn infant in Oxford, 1948-68. Fournal of Obstetrics and Gynaecology of the British Commonwealth, 77, 158.

deSa, D. J., and Nicholls, S. (1972). Haemorrhagic necrosis of the adrenal gland in perinatal infants: a clinico-pathological study. Fournal of Pathology, 106, 133.

Gruenwald, P. (1969a). Growth and maturation of the foetus and its relation to perinatal mortality. In Perinatal Problems: The Second Report of the 1958 British Perinatal Mortality Survey, p. 141. Ed. by N. R. Butler and E. D. Alberman. Livingstone, London.
Gruenwald, P. (1969b). Stillbirth and early neonatal death. In Perinatal Problems: The Second Report of the 1958 British Perinatal Mortality Survey, p. 163 . Ed. by N. R. Butler and E. D. Alberman. Livingstone, London.

Harrison, G., Rosan, R. C., and Sloane, A. (1970). Bronchiolitis induced by experimental acute and chronic oxygen intoxication in young adult rats. Fournal of Pathology, 102, 115.

Hawker, J. M., Reynolds, E. O. R., and Taghizadeh, A. (1967). Pulmonary surface tension and pathological changes in infants dying after respirator treatment for severe hyaline membrane disease. Lancet, $2,75$.

Kistler, G. S., Caldwell, P. R. B., and Weibel, C. R. (1967). Development of fine structural damage to alveolar and capillary lining cells in oxygen-poisoned rat lungs. Fournal of Cell Biology, 32, 605.

Northway, W. H., Jr., Rosan, R. C., and Porter, D. Y. (1967) Pulmonary disease following respirator therapy of hyalinemembrane disease: bronchopulmonary dysplasia. New England Fournal of Medicine, 276, 357.

Northway, W. H., Jr., Rosan, R. C., Shahinian, L., Jr., Castellino, R. A., Gyepes, M. T., and Durbridge, T. (1969). Radiologic and histiologic investigation of pulmonary oxygen toxicity in newborn guinea pigs. Investigative Radiology, 4, 148.

Patz, A. (1965). Effect of oxygen on immature retinal vessels. Investigative Ophthalmology, 4, 988.

Rowland, R., and Newman, C. G. H. (1969). Pulmonary complications of oxygen therapy. fournal of Clinical Pathology, 22, 192.

Shanklin, D. R., and Wolfson, S. L. (1967). Therapeutic oxygen as a possible cause of pulmonary haemorrhage in premature infants. New England fournal of Medicine, 277, 833.

Smallpeice, V., and Davies, P.A. (1964). Immediate feeding of premature infants with undiluted breast-milk. Lancet, 21349.

Correspondence to Dr. D. J. deSa, Harkness Laboratory, Radcliffe Infirmary, Oxford OX2 6HE. 